\title{
Indonesia Employees Mining Facing International Economic Era
}

\author{
Mustajir \\ Student at Doctoral Program of Law \\ Universitas Borobudur \\ Jakarta, Indonesia \\ mustajir.mustajir.2018@gmail.com
}

\author{
Faisal Santiago \\ Faculty of Law \\ Universitas Borobudur \\ Jakarta, Indonesia \\ faizalsantiago@borobudur.ac.id
}

\begin{abstract}
The ASEAN Economic Community (AEC) is one of the pillars of the realization of ASEAN Vision, together with the ASEAN Security Community (ASC) and ASEAN Socio-Cultural Community (ASCC). AEC is the ultimate goal of economic integration as stated in ASEAN Vision 2020. The establishment of the AEC is conducted through four strategic frameworks, namely the achievement of a single market and the unity of production base, a competitive economic region, equitable economic growth and integrated with the global economy. The free flow of the services sector is one of the key elements in the establishment of ASEAN as a single market and production base as well as the ideals of the AEC. In the era of AEC, Indonesia certainly expected to reap the benefits. First, the implementation of the AEC has the potential to make Indonesia as a supplier of energy and raw materials for industrialization in the ASEAN region due to the benefits derived from natural resource wealth. Second, the implementation of AEC expands the market share of Indonesia to the international level. This ASEAN single market opens up a stream of goods, services, investment, and an educated workforce. Third, the implementation of the AEC will encourage the entry of investment into Indonesia from within and outside ASEAN. The Indonesian Mining Sector must have a strategic plan in dealing with the AEC, but the strategy should also be able to elaborate the competent and competitive competing factors of the Indonesian Mining Workers such as providing training and certification of field competencies. The Indonesian Legal Regulation is also a safeguard for the mining workforce in order not to be eroded by foreign workers. The foreign mining workforce can enter easily into Indonesia with skill and unskilled skills. The role of the $\mathrm{S}$ tate in Indonesian mining has a significant role because of the many things that must be done to deal with the era of AEC.
\end{abstract}

Keywords: ASEAN economic community, employee, international economic era.

\section{INTRODUCTION}

The ASEAN Economic Community (AEC) or ASEAN Economic Community (AEC) comes into force in 2015. The AEC integrates all Southeast Asian countries in various fields, especially in the economic field, such as employment, investment, product, capital, investment to services. There are several advantages for countries that are ready to meet this AEC, among others, is to increase competition in the economic competition between countries, as well as more equitable economic growth in countries located in Southeast Asia.
For Indonesia, it is necessary to prepare as best as possible to face this AEC. This preparation is necessary not only for protecting or protecting domestic products but also on the world side of employment. Employment or human resources (HR) is one of the issues that arise related to the implementation of this AEC. These human resources are not only those working in government but also in the business world, especially those working in the small and medium enterprises (SME) and informal sector. AECs not only open up the flow of trade in goods or services but also the professional labor market, such as doctors, lawyers, accountants, and others.

In terms of employment we should be concerned that human resources will not be able to compete with workers from other countries that have better quality. This can be seen from several indicators that show the low quality of Indonesian human resources. According to a report from the UNDP in 2014, seen from the Human Development Index (HDI) or the Human Development Index (HDI), Indonesia ranks 108th out of 187 countries. We are under neighboring countries such as Singapore (ranked 18th), Malaysia (64th), Thailand (103th), and Philippines (rank 114). Similarly, if we look at the structure of the Indonesian labor force, according to data from the Central Bureau of Statistics (BPS), as of February 2014 the labor force has reached 125.3 million people. Of this number, 55.31 million (46.8 percent) of ele mentary school graduates (SD), followed by 21.06 million high school graduates, 18.91 million senior high school and 10.91 million vocational high schools. While the labor force with diploma level education is only 3.13 million and undergraduate only 8.85 million people only. The low quality of education in Indonesia will weaken Indonesia's competitiveness in facing the ASEAN economic community 2015 .

AECnwhile, according to the Asian Productivity Organization (APO), the readiness of Indonesian workers shows that from every 1,000 Indonesian workers only about 4.3 percent are skilled, while the Philippines is 8.3 percent, Malaysia (32.6) and Singapore (34.7). One of the things that also need to be aware of or observed from the AEC is about free flow of skilled labor. Skilled labor that can be freely exchanged at the AEC in 2015 refers to the MRA (mutual recognition agreement) agreement agreed upon by ASEAN member countries. MRA is an opportunity that is shared by all ASEAN countries to mutually recognize or accept some or all aspects of the assessment results such as test results or a certificate of competence. Such expert labor exchange 
should be accepted as a consequence of the agreement, whereas in terms of human resources, the Indonesian workforce has some weaknesses that still need to be addressed, such as the low labor productivity, the uncertainty of the wage, the average of education and ability low foreign language, high unemployment rate, inadequate skills and skills, and other weaknesses. Looking at the conditions surrounding the human resources or labor of Indonesia above, it is interesting to review how to prepare Indonesian human resources to compete in the ASEAN Economic Community (AEC) that will soon be implemented.

The establishment of the ASEAN Community from 2020 was accelerated to 2015, agreed upon by ASEAN Heads of State at the 12th ASEA N Su mmit. ASEAN Commun ity 2015 is divided into 3 pillars, namely: ASEAN Security Community, ASEAN Economic Community and ASEAN Socio-Cultural Community. In the economic field, it began with the passing of the Bangkok Declaration of 1967 aimed at accelerating economic growth, social progress and cultural development. In its development, ASEAN economic cooperation leads to the establishment of an ASEAN Economic Community whose implementation runs relatively faster than cooperation in the field of politics-security and socio-culture. The 9th ASEAN Summit in Bali in 2003 resulted in the Bali Concord II affirming that the ASEAN Economic Community (AEC) will be directed to the establishment of a regional economic integration. Establishment of trade transaction fees, improving trade and business facilities, and enhancing the competitiveness of the SME sector.

In addition, the establishment of AEC will also facilitate and enhance access to intra-ASEAN markets and increase transparency and accelerate adjustment of domestic regulations and standardization. The establishment of the ASEAN Economic Community will also provide opportunities for ASEAN member countries to expand the scope of economies, reduce poverty and socio-economic disparities, increase attractiveness as a destination for investors and tourists, reduce trade transaction costs and improve trade and business facilities. According to Pane (2014) in essence AEC aimed positively, that is to integrate economic power in the ASEAN region in order to be able to compete in the global level with other economic power. In the AEC agreement, the 4 (four) pillars of the blueprint are;

1. Towards a single market and production based, free trade flow for goods, services, investments, skilled workers, and capital.

2. Toward the creation of a highly competitive regional economic region (regional competition policy, IPRs action plan, infrastructure development, ICT, energy cooperation, taxation, and SME development).

3. Towards a region with equitable economic development through the development of SMEs and Initiative for ASEAN Integration (IAI) programs.

4. Toward full integration of the global economy (a coherent approach in external economic relations and encourage participation in a global supply network).

The four pillars of the AEC are interrelated and supportive of each other. ASEAN as a single market and international production base must have high economic competitiveness, either as a region within the framework of competition with other regions / countries, as well as among individual members.

\section{RESEARCH METHODS}

This study was conducted using the Normative Juridical approach. The literature is used as the main material, namely the primary legal material consisting of basic norms or rules, rules or basic rules, and legislation. In addition, secondary legal materials are used as secondary data covering primary, secondary, and tertiary legal materials of research results of academics and legal experts.

\section{PROBLEM}

1. How can the Government Efforts to Deal with AEC?

2. How is the Development of Indonesian Mining Workers Facing AEC?

\section{DISCUSSION}

\section{A. Efforts that the Government can take in facing the AEC}

Serian Wijatno and Ariawan Gunadi in www.suaradewata.com (2013) revealed that Indonesia can face the ASEAN Economic Community with its strategy as follows:

a) Take advantage of trade barriers to curb the flood of foreign products and services;

b) Create competent employers' resources through education and training;

Form a free trade agreement dispute forum with simple and clear procedures so that legal certainty.

The government should also make improvements to the quality of human resources of mining workers in Indonesia in order to improve the competitiveness of Indonesian mining workers in the ASEAN market. Not only in terms of educational ability, expertise, and productivity but equally important is the provision of foreign language mastery skills for Indonesian mining workers. As has been widely reported that countries in ASEAN such as Thailand and even Australia have been teaching Indonesian language on education. This could pose a threat to the local mining workforce of a foreign mining workforce. The government also needs to spell out the various strategies embodied in policies, programs and activities supported by serious implementation through cooperation between the Government, Academicians and the Indonesian (industrial) industry so that Indonesia can be better prepared to face the AEC in 2015. In addition, good infrastructure needs to be addressed. Efforts to improve the capability and competitiveness of mining workers and companies in Indonesia for example, can be done by providing convenience in obtaining education / training.

Socialization should also be done by the government in the context of AEC preparation. The socialization is not solely about how to penetrate the ASEAN market but much more important is how the national entrepreneurs can survive in the local market amid the large trade of services from ASEAN, which will certainly involve the human resources of skilled and skilled mining workers. Improving the protection of mining workers also needs to be done. Therefore, the government needs to recognize the importance 
of better regulation of foreign mining worker placement even though low-skill jobs are also widely available.

The Indonesian government needs to take concrete steps in order to compete against these foreign workers. There are some things that need to be of concern or note to the world of employment before the time our country will actually enter the AEC. First, the government needs to enact a major law or regulation that contains comprehensive and comprehensive arrangements in the employment field. This is the guidance as the rule of the world of employment in Indonesia when entering the AEC. The law is also expected to protect Indonesian mining workers.Maintaining the Integrity of the Specifications

\section{B. Development of Indonesian Mining Workers in the face of $A E C$}

In the face of competition in the ASEAN Economic Community in 2015, the development of human resources (HR), especially the mining workforce is very important. The development of the mining workforce is done to improve skills, technical, theoretical, conceptual, and moral. This development needs to be implemented in a planned and sustainable manner. Development should be carefully crafted and based on scientific methods, and be guided by the skills that the company needs for the present and the future.

Development will encourage mining workers to work harder. This is because the mining worker who has been well aware of his duties and responsibilities will seek to achieve a higher level of work morale. So the purpose of the development of labor is to improve the work ability or improve the effectiveness of employees in achieving the results of work that has been established. Improving the effectiveness of this work can be done by improving the knowledge of employees, emp loyee skills, and the attitude of the workforce to his duties.

The development of the mining workforce is done to close the gap between the skill or the ability of the workforce with the request of office. Besides, it is also to improve the efficiency and effectiveness of the work of mining workers in achieving the set goals. So although this development is time consuming and the cost is quite expensive, but still implemented by the company because it is an investment in human resources. Mining development programs should have successful plans at every level, career path design, rotation, and leadership development to address changing business environments. The focus of the development of the mining workforce is no longer the weakness or lack of manpower, but rather the interest and strength, that is by developing strength based training, that is training that is focused on one's strength.

The education and training of the mining workforce is conducted to master hard competence to improve hard skills and knowledge and soft competence to improve workforce behavior. Stages of HR development as follows:

a. Identify development needs.

In this stage, the most appropriate development process for certain individuals is identified by assessing the strenghts and areas for development of each individual (mining workforce). Assessment can be done through the assessment center pattern or also through the observation and evaluation of each supervisor (this is more practical than having to use asses sment center). b. Formulate development programs suitable for the relevant mining workforce.

In the formulation of the assessment program the development of assessment results is not only based on the weakness of the mining workforce, but it should be more based on the strength of the mining workforce (this approach is called as strenght based development). The type of program or development process that is organized also should not be in the form of classroom training. There are many other alternative development programs such as: 1) Mentoring (the mining workforce is considered senior and has the special expertise to mentor to a number of other workers, 2) Project / special assignment (3) Job enrichmnet (3) enriching the weight of work), 4) On-the-job training.

c. Monitoring and evaluation of the implementation of development programs that have been prepared.

In this phase, each program implementation progress is monitored for its effectiveness and then at the end of the program is evaluated its impact on improving the performance of the relevant mining workforce, as well as on business performance.

For the purposes of quality improvement, basically can be done through 3 main lines, namely:

a. Formal educational channels

It consists of general and vocational education from elementary, junior and senior high schools, and colleges. This formal education channel aims to equip one with the foundations of knowledge, theory and logic, general knowledge, analytical skills, and the development of character and personality.

b. Line of work training

This path is a process of skill development and work skills. The purpose of this workshop is to improve professional skills and prioritize practice rather than theory. The work training system can be viewed as a supplement or completeness of the formal education system. The assertiveness of community values concerning the mental attitude, morals and dedication of a person is developed through the formal education system. While the mental attitude, morale and dedication to the implementation of tasks can be developed through a system of work training. Basically the value of talent development, creativity, innovation, skills and work motivation are grown in the formal education environment and developed in the process of work training.

c. Path of work experience

This path is a vehicle where one can improve his technical knowledge and work skills by observing others, imitating, and doing his own work tasks that he / she is engaged in. By doing repetitive work, someone will be more adept at doing his job, besides it will be able to find more practical, efficient and better ways to carry out their work.

Approach to work training and experience can be done jointly in the form of apprenticeship and on the job training. The line of work experience can be well developed if a person has the basics of knowledge, skills and skills he has gained from formal education and the training path. The se three channels are conducted as an effort to improve or develop the quality of human resources.

Through the development of a good mining workforce is expected Indonesia human resources can be more increased 
in terms of mastery of knowledge, skills and technical, conceptual and moral skills, and more increased efficiency and effectiveness of work. It is thus expected that they are ready to compete with human or labor resources from other countries when tomorrow by 2015 the ASEAN Economic Community is enacted.

\section{CONCLUSIONS}

Indonesia must immediately prepare itself in the face of the ASEAN Economic Community which has been ongoing since 2015. Where at this time has been felt that with the entry of foreign workers to Indonesia. For that attention to improving the quality of human resources or manpower, especially the workforce in mining becomes something urgent to do. Given the mining sector is a very strategic sector that greatly affects the economy of the State. Through training programs, skills, skills, knowledge, development and protection of mining workers primarily carried out by the government with the help of various parties such as academics and entrepreneurs are expected to produce quality and ready to compete for quality mining workforce which is now underway.

\section{REFERENCES}

[1] Forum Human Capital Indonesi, Excellent People Excellent Business, Pemikiran Strategik Mengenai Human Capital Indonesia, First Print, Jakarta : Gramedia PustakaUtama, 2007.

[2] Handoko, and T. Hani, Manajemen Personalia dan Sumber Daya Manusia, Twenty One Print, Yogyakarta : BPFE, 2014.

[3] Hasibuan, Malayu S. P., Manajemen Sumber Daya Manusia. Eleven Print, Jakarta: Bumi Aksara, 2008.

[4] Heidracman Ranupandojo and Suad Husnan, Manajemen Personalia. Cetakan Kesepuluh. Yogyakarta: BPFE, 2002.

[5] Eva Septiana Pane, Tinjauan Kesiapan SDM / Tenaga Kerja Indonesia Menghadapi Masyarakat Ekonomi ASEAN, 2014.

[6] Bagus Prasetyo, Menilik Kesiapan Dunia Ketenagakerjaan Indonesia Menghadapi MEA, 2014.

[7] Jurnal Rechts Vinding Online, Media Pembinaan Hukum Nasional., in press.

[8] Eka Ruhana, Pengembangan Kualitas Sumber Daya Manusia vs Daya Saing Global. Jurusan Administrasi Bisnis FIA UB, 2012.

[9] Wuryandani, Dewi, Peluang dan Tantangan SDM Indonesia Menyongsong Era Masyarakat Ekonomi ASEAN, Jurnal Info Singkat Ekonomi dan Kebijakan Publik Vol. VI, No. 17/I/P3DI/September/2014,2014., in press.

[10] http://regional.kompasiana.com/2014/06/28/kesiapan-sumber-dayamanusia-sdm-indonesia-menyongsong-implementasi-masyarakatekonomi-asean-mea-2015-664888., internet.

[11] http://www.antaranews.com/berita/458152/indonesia-harus-siapkansdm-t angguh-hadapi-mea-2015., internet.

[12] http://www.suaradewata.com/index.php/bacapost ing/273/Menyambut-Masyarakat-Ekonomi-ASEAN-awalMEAakhir-2015., internet. 